\title{
Evidence for a Placento-Insular Axis in the Rat Fetus
}

\author{
F. Sodoyez-Goffaux, J. C. Sodoyez and C. J. De Vos \\ Departments of Paediatrics and Internal Medicine, University of Liège, Liège, Belgium
}

Summary. Rat pups delivered by caesarian section one day before term, either remained attached to (experimental group) or were separated from their placenta (control group). Both groups were transferred into an incubator and their metabolic parameters studied. In the control group, plasma amino acid concentration fell from 11.2 to $6.9 \mathrm{mmol} / \mathrm{l}$, plasma insulin fell from 151 to $45 \mu \mathrm{U} / \mathrm{ml}$ and blood glucose fell from 3.5 to $2.6 \mathrm{mmol} / 1$ during the first hour of extrauterine life. In the breathing feto-placental units, plasma amino acid concentration remained at its birth level, plasma insulin remained high $(109 \mu \mathrm{U} /$ $\mathrm{ml})$ causing rapid hypoglycaemia $(1.63 \mathrm{mmol} / \mathrm{l})$. An immediately postnatal glucagon and corticosterone surge was visible only in the experimental group. A partially purified placental extract (molecular weight 6000 to 30000 ) stimulated insulin secretion in vivo (fasted adult rats) and in vitro (isolated neonatal islets). It is concluded that the placenta maintains fetal hyperinsulinaemia by creating fetal hyperaminoacidaemia and, possibly, by secreting a beta cytotropic factor.

Key words: Rat fetus, feto-placental units, placental extract, glucose, amino acids, non esterified fatty acids, insulin, glucagon, corticosterone, isolated islets, placento-insular axis.

During the last 5 days of gestation, the weight of a rat fetus increases six-fold and plasma insulin concentration is higher than in adult rats, peaking at about $500 \mu \mathrm{U} / \mathrm{ml} 2$ days before term. Coincidence of rapid body growth and hyperinsulinaemia supports the hypothesis that insulin might be a fetal growth hormone or, at least, a growth factor for sensitive tissues.
In other species including man, the development of some fetal tissues also seems to be related to the rate of insulin secretion in utero. Macrosomia is a common feature of infants of diabetic mothers. Isolated hyperinsulinaemia during fetal life, as in infants with insulin secreting adenoma, usually yields heavier newborns. Likewise, experimentally produced fetal hyperinsulinaemia in the presence of euglycaemia caused macrosomia in the rhesus monkey [1]. By contrast, fetuses deprived of insulin, such as infants suffering from transient neonatal diabetes [2] or congenital absence of islets of Langerhans [3], are light for gestational age.

If insulin is a fetal growth factor, then more information is required on the regulation of insulin secretion during fetal life. Previous studies on the rat fetus have shown 1) that the high plasma insulin concentration resulted from high rate of production and not slow degradation [4] 2) that the rates of insulin and glucagon secretion by isolated fetal islets could be modulated by fuels and hormones [5] and 3) that the presence of the placenta was essential for maintaining fetal hyperinsulinaemia [4]. The aim of the present study is to examine the mechanism whereby the placenta exerts this action.

\section{Materials and Methods}




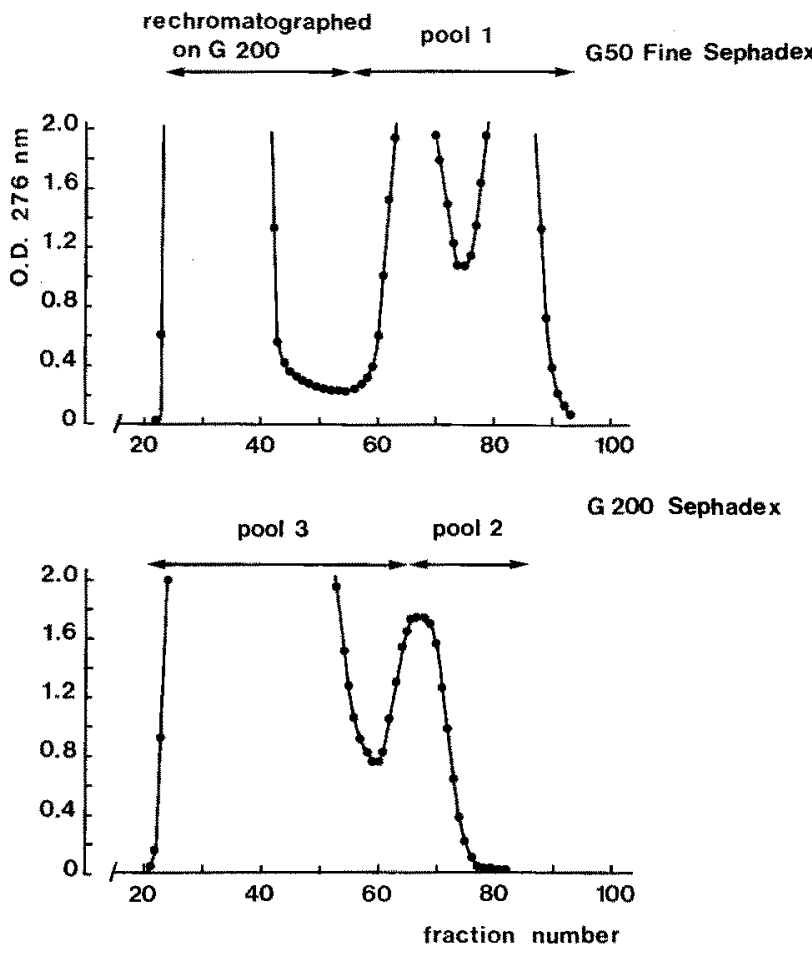

Fig. 1. Elution profile of the ultracentrifugation supernatant of placental extract (50 placentas) after G50F Sephadex chromatography. Four ml fractions were collected and their protein content estimated by reading the optical density at $\lambda_{276 \mathrm{~mm}}$ (upper panel). Fractions 22-47 were pooled, lyophilised and rechromatographed on G200 Sephadex (lower panel). Buffer was $0.05 \mathrm{~mol} / 1$ $\mathrm{NH}_{4} \mathrm{HCO}_{3}, \mathrm{pH} 8.2$

remained attached to their placentas and care was taken not to disturb the circulation of fetal blood through the umbilical cord. The whole feto-placental units (FPU) were removed from the uterus and transferred into the incubator. The timing of blood sampling was the same as for the control group. The pups of the groups 2 and 3 breathed normally and were apparently well oxygenated.

Adult rats were deprived of food for $24 \mathrm{~h}$ and anaesthetised with nembutal $(60 \mathrm{mg} / \mathrm{kg}$, IP). Placental extract (pool 1-3) was dissolved in $9 \mathrm{~g} / 1 \mathrm{NaCl}$ and injected via a jugular vein catheter. Blood samples drawn before and 10,20 and 30 min after the IV injection and were analysed for blood glucose and plasma IRI concentrations.

\section{Metabolite and Hormone Assays}

Fetal blood was collected from the axillary artery. Glucose concentration $(20 \mu \mathrm{l}$ blood) was measured by the hexokinase method. Amino acids were measured on the trichloroacetic acid supernatant of $50 \mu \mathrm{l}$ plasma using a colorimetric method [6]. Non esterified fatty acids (NEFA) were extracted according to Dole [7] by successively adding to $100 \mu \mathrm{l}$ plasma $1.5 \mathrm{ml}$ isopropanol-heptane$1 \mathrm{~mol} / 1 \mathrm{H}_{2} \mathrm{SO}_{4}(40-10-1)$ and, after thorough mixing, $0.9 \mathrm{ml}$ heptane and $0.6 \mathrm{ml}$ distilled water. After centrifugation, $0.7 \mathrm{ml}$ of the upper phase were dried under nitrogen and the NEFA measured by a colorimetric method [8]. Immunoreactive insulin (IRI) was assayed on $20 \mu \mathrm{l}$ plasma by the double antibody method of Hales and Randle [9] using a rat insulin standard (lot R171, Novo Com- pany, Copenhagen). Plasma immunoreactive glucagon (IRG) concentration was kindly measured by Dr. R. Assan (Paris) using $30 \mathrm{~K}$ antiglucagon serum. Other plasma IRG concentrations were assayed in our laboratory, using $100 \mu \mathrm{l}$ plasma, the same $30 \mathrm{~K}$ antiserum and ${ }^{125} \mathrm{I}$ glucagon prepared by the Novo Co, Copenhagen [10]. Plasma corticosterone concentration ( $10 \mu \mathrm{I}$ serum) was measured using a specific radioimmunoassay [11].

\section{Preparation of Islets of Langerhans}

One day after birth, rat pups were killed by decapitation and their islets isolated by mild collagenase digestion and microdissection. In each experiment, three lots of 10 islets were incubated $60 \mathrm{~min}$ at $37^{\circ} \mathrm{C}$ in $2 \mathrm{ml} \mathrm{Krebs}$ Ringer bicarbonate buffer supplemented with $10 \mathrm{mg} / \mathrm{ml}$ crystallised bovine serum albumin (Sigma Chemical Co, St Louis, Mo) and $2.8 \mathrm{mmol} / 1 \mathrm{D}$-glucose, with or without $40 \mathrm{mg}$ lyophilised placental extract (pool 2, see below) or $16.7 \mathrm{mmol} / 1$ D-glucose. The experimental procedure has been detailed elsewhere [4].

\section{Preparation and Fractionation of a Placental Extract}

Approximately 50 rat placentas obtained 2 days before term were homogenised in $50 \mathrm{ml}$ ice-cold $0.05 \mathrm{~mol} / 1 \mathrm{NH}_{4} \mathrm{HCO}_{3}$ buffer, $\mathrm{pH}$ 8.2 , using a Polytron homogeniser. The homogenate was centrifuged at $15000 \mathrm{~g}$ for $30 \mathrm{~min}$ and the supernatant ultracentrifuged at $100000 \mathrm{~g}$ for $180 \mathrm{~min}$. The ultracentrifugation supernatant was lyophilised, redissolved in $20 \mathrm{ml}$ ammonium bicarbonate buffer and applied to a $2.7 \times 50 \mathrm{~cm}$ G50 fine Sephadex column run with the same buffer. The fractions corresponding to the void volume and the first fractions of the internal volume were pooled and lyophilised. The dry residue was redissolved in $20 \mathrm{ml}$ of ammonium bicarbonate buffer and rechromatographed on a $2.7 \times$ $50 \mathrm{~cm}$ Sephadex G200 gel. The fractions corresponding to the total column volume were pooled and lyophilised (pool 2). The other fractions of the G50 and G200 chromatograms respectively made up pools 1 and 3 (Fig. 1).

\section{Statistical Evaluation of the Results}

The Student's $t$ test on paired data was applied to evaluate the insulin secretory effect of placental extract pool 2 on isolated neonatal islets. In all other instances, the $t$ test was calculated on unpaired data.

\section{Results}

\section{Effect of the Placenta on the Metabolic Status of the Pups}

As indicated by Table 1, the presence of the placenta caused but a mild metabolic acidosis.

Plasma IRI concentration decreased rapidly in the control group (Table 2). Blood glucose concentration remained at its birth level after $30 \mathrm{~min}$ and later decreased. Plasma amino acid concentration immediately fell, reaching half its birth value after 60 min of extrauterine life. In contrast, in the FPU, plasma IRI concentration remained high, blood glucose concentration decreased rapidly reaching 
Table 1. Acid-base status of control pups and of feto-placental units. Mean \pm SEM. Number of pups in parentheses

\begin{tabular}{lccccc}
\hline & \multicolumn{2}{l}{ Control } & & Feto-placental units \\
\cline { 2 - 3 } & $30 \min (\mathrm{n}=5)$ & $60 \min (\mathrm{n}=5)$ & & $30 \min (\mathrm{n}=4)$ & $60 \mathrm{~min}(\mathrm{n}=5)$ \\
\hline $\mathrm{pH}$ & $7.28 \pm 0.02$ & $7.39 \pm 0.03^{\mathrm{a}}$ & & $7.24 \pm 0.03$ & $7.32 \pm 0.02$ \\
$\mathrm{pCO} \mathrm{mmHg}_{2}$ & $39 \pm 5$ & $42 \pm 4$ & $45 \pm 3$ & $39 \pm 3$ & $-5.5 \pm 1.8^{\mathrm{b}}$ \\
base excess $\mathrm{mmol} / \mathrm{l}$ & $-7.7 \pm 2.7$ & $0.4 \pm 1^{\mathrm{a}}$ & & $-8.2 \pm 1.8$ & \\
\hline
\end{tabular}

Different from the $30 \mathrm{~min}$ value: ${ }^{\mathrm{a}} \mathrm{p}<0.05$

Different from the control pups separated from the placenta after the same length of extrauterine life: ${ }^{b} \mathrm{p}<0.05$

Table 2. Plasma metabolite and hormone concentrations during the first hour of extrauterine life in control pups separated from the placenta and in breathing feto-placental units. Mean \pm SEM. Number of pups between parenthesis

\begin{tabular}{|c|c|c|c|c|c|}
\hline & \multirow[b]{2}{*}{ At birth } & \multicolumn{2}{|l|}{ Control } & \multicolumn{2}{|c|}{ Feto placental units } \\
\hline & & $30 \mathrm{~min}$ & $60 \mathrm{~min}$ & $30 \mathrm{~min}$ & $60 \min$ \\
\hline Blood glucose $\mathrm{mmol} / 1$ & $3.49 \pm 0.13(40)$ & $3.48 \pm 0.26(26)$ & $2.61 \pm 0.24^{d}(17)$ & $2.76 \pm 0.18^{c}(29)^{e}$ & $1.63 \pm 0.14^{\mathrm{d}}(19)$ \\
\hline Plasma amino acids $\mathrm{mmol} / \mathrm{l}$ & $11.2 \pm 0.3(16)$ & $8.9 \pm 0.3^{\mathrm{d}}(16)$ & $6.9 \pm 0.3^{\mathrm{d}}(17)$ & $11.8 \pm 0.6^{\mathrm{h}}(16)$ & $10.5 \pm 0.2^{\mathrm{h}}(16)$ \\
\hline Plasma NEFA $\mu \mathrm{mol} / 1$ & $205 \pm 17(11)$ & $243 \pm 30(8)$ & $233 \pm 18(8)$ & $228 \pm 21(8)$ & $267 \pm 33(9)$ \\
\hline Plasma IRI $\mu \mathrm{U} / \mathrm{ml}$ & $151 \pm 7(40)$ & $74 \pm 5^{d}(26)$ & $45 \pm 4^{d}(17)$ & $197 \pm 19^{\mathrm{h}}(29)$ & $109 \pm 11^{\mathrm{d}}(19)$ \\
\hline Plasma IRG $^{\mathrm{i}} \mathrm{pg} / \mathrm{ml}$ & $510 \pm 36(30)$ & $515 \pm 26(14)$ & $507 \pm 39(17)$ & $663 \pm 47^{a}(15)^{\mathrm{c}}$ & $968 \pm 39^{d}(17)^{h}$ \\
\hline Plasma corticosterone $\mathrm{ng} / \mathrm{ml}$ & $45 \pm 7(5)$ & $54 \pm 7(6)$ & $26 \pm 2^{\mathrm{a}}(5)$ & $101 \pm 18^{a}(6)^{e}$ & $124 \pm 11^{\mathrm{d}}(4)^{\mathrm{h}}$ \\
\hline
\end{tabular}

Different from corresponding value at birth: ${ }^{a} p<0.05{ }^{b} p<0.01 \quad{ }^{c} p<0.005{ }^{d} p<0.001$

Different from control pups separated from the placenta after the same length of extrauterine life: ${ }^{\mathrm{e}} \mathrm{p}<0.05 \quad \mathrm{f}^{\mathrm{f}} \mathrm{p}<0.01 \quad \mathrm{~g} \mathrm{p}<$ $0.005{ }^{\mathrm{h}} \mathrm{p}<0.001{ }^{\mathrm{i}}$ These IRG determinations were kindly performed by Dr. Assan

$1.63 \mathrm{mmol} / 1$ after $60 \mathrm{~min}$, and plasma amino acid concentration remained at its birth level.

Plasma IRG and corticosterone concentrations varied little in the control group. On the contrary, a glucagon and corticosterone surge was observed in the FPU.

\section{Effect of Hyperinsulinaemia on the Metabolic Status of Newborn Pups}

In order to distinguish better the effects of the placenta and of hyperinsulinaemia in the FPU, one day preterm fetuses received an injection of $0.5 \mu \mathrm{g}$ rat insulin at birth via the umbilical vein. The cord was ligated and cut immediately after the injection, and metabolic parameters were measured one $h$ later. Pups of the same litters were used as controls. Sixty minutes after insulin, plasma IRI concentration was still higher in the experimental than in the control group (Table 3). This was associated with a marked hypoglycaemia and a small decrease in plasma amino acid concentration. Plasma IRG concentration was equal in both groups.

\section{Effect of a Placental Extract on Insulin Secretion}

As shown by Figure 2 a significant insulin secretory effect was observed only with placental extract pool 2.
Table 3. Effect of IV injection of $0.5 \mu \mathrm{g}$ insulin at birth on metabolic parameters measured $60 \mathrm{~min}$ later. Mean $\pm \mathrm{SEM}$, number of pups in parentheses

\begin{tabular}{lcc}
\hline & Control & Insulin injected \\
\hline Blood glucose, mmol/1 & $2.92 \pm 0.21(12)$ & $0.84 \pm 0.08^{\mathrm{b}}(13)$ \\
Plasma amino acids, mmol/1 & $5.7 \pm 0.2(10)$ & $5 \pm 0.1^{\mathrm{a}}(12)$ \\
Plasma IRI $\mu \mathrm{U} / \mathrm{ml}$ & $59 \pm 9(4)$ & $330 \pm 22^{\mathrm{b}}(4)$ \\
Plasma IRG pg/ml & $237 \pm 20(10)$ & $232 \pm 22(10)$ \\
\hline
\end{tabular}

Different from control: ${ }^{\mathrm{a}} \mathrm{p}<0.005,{ }^{\mathrm{b}} \mathrm{p}<0.001$

Table 4. Effect of placental extract (pool 2) and of high glucose on IRI release by isolated islets of 1 day old pups. Mean \pm SEM $(\mathrm{n}=15)$

$\begin{array}{lll}\text { Glucose } & \text { Glucose } & \text { Glucose } \\ 2.8 \mathrm{mmol} / 1 & \begin{array}{l}2.8 \mathrm{mmol} / 1 \\ + \text { pool 2 }^{\mathrm{c}}\end{array} & 16.7 \mathrm{mmol} / 1 \\ & \end{array}$

IRI release,

$\mu \mathrm{U} / \mathrm{h} /$ islet $\quad 39.5 \pm 4.3 \quad 62.9 \pm 9.9^{\mathrm{a}} \quad 224.9 \pm 11.9^{\mathrm{b}}$

Different from IRI release in the presence of low glucose: ${ }^{\mathrm{a}} \mathrm{p}<0.01,^{\mathrm{b}} \mathrm{p}<0.001^{\mathrm{c}}$ The concentration of placental proteins was $20 \mathrm{mg} / \mathrm{ml}$ and corresponded to 2 placenta-equivalents $/ \mathrm{ml}$

None of the 3 pools significantly influenced blood glucose concentration.

The insulin secretagogue effect of pool 2 was assessed on isolated neonatal islets, the reactivity of 

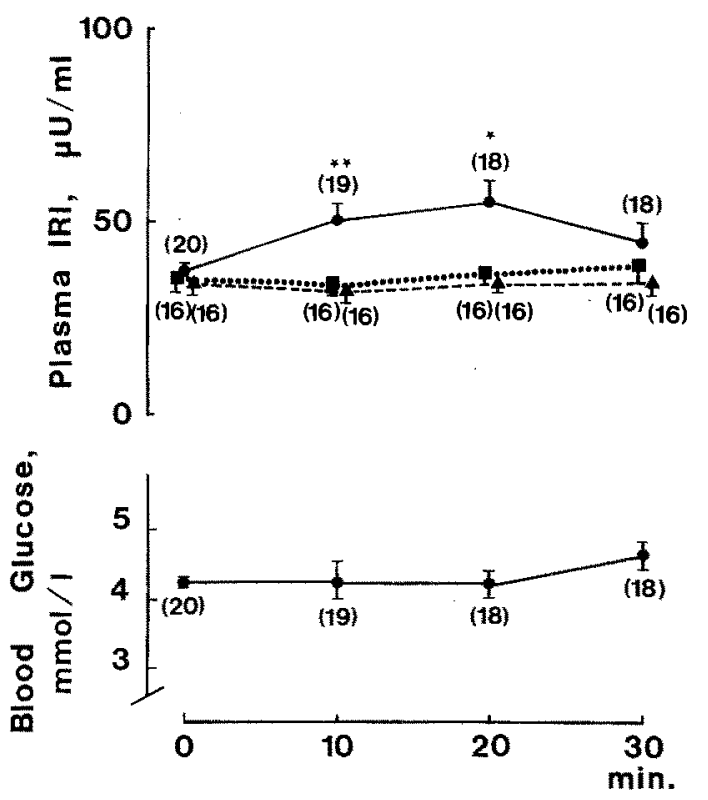

Fig. 2. Effect of I. V. injection of placental extract (pool 1 $\mathbf{\square} \cdot \ldots \mathbf{n}$, pool $2-$, pool $3 \mathbf{\Lambda}--\mathbf{A}$ ) on plasma IRI (upper panel) and blood glucose (lower panel) concentrations of nembutal anesthetised fasted adult rats. Each rat received 10 placenta equivalents. Mean $\pm S E M$, number of experiments between parenthesis. Different from 0 value, $* \mathrm{p}<0.025$ ** $\mathrm{p}<0.005$

which was verified by measuring their insulin response in the presence of a high glucose concentration. As shown in Table 4, the neonatal islets were viable and highly reactive to glucose and pool 2 elicited a significant increase of insulin secretion.

\section{Discussion}

The isolated breathing feto-placental unit is a rather unphysiological model. Blood flow is maintained through the placenta and thus this organ becomes an oxygen consumer. As the pups breath, an adequate pulmonary blood flow must be maintained by the right heart. Thus, total blood volume, heart work and oxygen consumption are increased. As shown by the almost normal acid-base status of these units, this peculiar condition seems well tolerated during experiments of short duration.

Instead of decreasing rapidly as in pups separated from their placenta, plasma IRI concentration remained as high in the isolated FPU as in those left in utero. This could possibly be explained by patency of porto-caval shunts and decreased extraction of insulin by the liver of the isolated FPU. This possibility appears unlikely because hepatic uptake of $\left[{ }^{125} \mathrm{I}\right]$ monoiodoinsulin was as rapid and of similar mag- nitude when the labelled hormone was injected into the vitelline vein of intact eggs in utero as when it was injected into the umbilical vein of breathing pups separated from their placenta (data not shown). We therefore favour the alternative explanation, that the insulin secretion rate is higher in the isolated FPU than in the control pups separated from their placenta.

In pups separated from their placenta, exogenous insulin exerted the expected effects of lowering blood glucose and plasma amino acid concentration. A rapid fall in blood glucose concentration was also observed in the FPU. However, despite hyperinsulinaemia, plasma amino acid concentration remained high. This suggests that, even though separated from the maternal circulation, the placenta released its intracellular amino acids into the fetal blood [12]. Sustained insulin secretion in the face of hyperaminoacidaemia and deepening hypoglycaemia indicates that, of these 2 fuels, amino acids may be more important insulin secretagogue agents at this stage of $\mathrm{B}$ cell maturation.

It is possible that the high level of plasma amino acids is not the only factor which maintains high fetal $B$ cell secretion. The placenta could also secrete beta cytotropic factors. A fraction of an aqueous placental extract (pool 2) exerted a moderate but significant insulinogenic activity in vivo and in vitro. This conclusion was reached after verification that pool 2 did not contain insulin, that it did not degrade added insulin and that it did not interfere with the radioimmunoassay of insulin. According to its chromatographic properties, the molecular weight of the active substance was in the range of 6 to 30,000 daltons. Its chemical nature remains to be established. It could be placental lactogen, an insulinogenic fragment of proopiocortin (such as CLIP), or another substance.

Before assigning a physiological role to this insulinogenic substance of placental origin, experimental verification is required that this substance is actually secreted into the fetal blood and that its concentration in the fetal blood is above the threshold of $B$ cell reactivity.

In the control pups the postnatal glucagon surge did not occur immediately after birth as reported by others $[13,14,15]$. Differences in the handling of the newborns could explain these discrepancies. In the present study, the pups were immediately transferred into a warm, humidified and oxygenated atmosphere in order to minimize adrenergic stimulation induced by cold and anoxia. The early glucagon surge observed in the FPU could be due to several factors, one of which might be hypoglycaemia. The stimulation of A cells is not likely due to hypoglycaemia because more profound hypoglycaemia caused by 
exogenous insulin did not modify plasma IRG concentration in pups separated from their placenta. This finding corroborates previous data obtained in vivo $[16,17]$ and in vitro [5], and strengthens the contention that fetal and neonatal $\mathrm{A}$ cells are either slightly or unreactive to glucose. The immediate postnatal glucagon surge of the FPU might rather be explained by persisting hyperaminoacidaemia and/or by the stress imposed by overload of the cardio-pulmonary system [18].

The possible interrelationships between the placenta, the B cells and the insulin-sensitive tissues may therefore be viewed as follows. In utero, the placenta actively transports amino acids [19], and could possibly release a beta cytotropic factor. Both stimulate fetal insulin secretion. High plasma insulin concentration, in turn, favours amino acid and, to a much greater extent, glucose uptake by insulin sensitive tissues [20]. Finally, high glucose utilisation in the fetus steepens the downward glucose gradient between mother and fetus and accelerates its transplacental passage. In this manner, amino acids and glucose utilisation by the fetus would be coupled by means of the placento-insular axis. The present hypothesis could also explain fetal hypoinsulinaemia in growth retardation due to placental insufficiency.

At birth, when the cord is cut, the placental supply of amino acids and of beta cytotropic factor is interrupted and insulin secretion is turned off.

Acknowledgements. This work was supported by grants from the National Fund for Scientific Research, Brussels, Belgium. We are grateful to Dr. Assan for performing some of the glucagon assays and to Mr. J. Sulon for performing the radioimmunoassay of corticosterone. The secretarial assistance of Miss M. Fodor and the bibliographical assistance of Dr. Willot (Schering Pharma) are gratefully acknowledged.

\section{References}

1. Susa JB, McCornick KL, Widness JA, Singer DB, Oh W, Adamsons K, Schwartz R (1979) Chronic hyperinsulinemia in the fetal rhesus monkey. Effects on fetal growth and composition. Diabetes 28: 1058-1063

2. Sodoyez-Goffaux F, Sodoyez IC (1977) Transient diabetes mellitus in a neonate. J Pediatr 91: 395-399

3. Dodge JA, Laurence KM (1977) Congenital absence of islets of Langerhans. Arch Dis Child 52: 411-419

4. Sodoyez-Goffaux F, Sodoyez JC, De Vos CJ (1979) Insulin secretion and metabolism during the perinatal period in the rat. J Clin Invest 63: 1095-1102

5. Sodoyez-Goffaux F, Sodoyez JC, De Vos CJ, Foà PP (1979) Insulin and glucagon secretion by islets isolated from fetal and neonatal rats. Diabetologia 16: 121-123
6. Malangeau P, Bourdon R, Nicaise AM, Masson B (1963) Dosage des acides aminés dans les liquides de lorganisme. Ann Biol Clin (Paris) 21: 3-13

7. Dole VP (1956) A relation between non esterified fatty acids in plasma and the metabolism of glucose. J Clin Invest 35: 150-154

8. Noma A, Okabe H, Kita M (1973) A new colorimetric microdetermination of free fatty acids in serum. Clin Cxim Acta 43: $317-320$

9. Hales CN, Randle PJ (1963) Immunoassay of insulin with insulin-antibody precipitate. Biochem J 88: 137-146

10. Unger RH, Aguilar Parada E, Muller WA, Eisentraut AM (1970) Studies of alpha cell function in normal and diabetic subjects. J Clin Invest 49: 837-848

11. Sulon J, Demey-Ponsart L, Beauduin P, Sodoyez JC (1978) Radioimmunoassay of corticosterone, cortisol and cortisone: their application to human cord and maternal plasma. J Steroid Biochem 9: 671-676

12. Schneider H, Möhlen KH, Dancis J (1979) Transfer of aminoacids across the in vitro perfused human placenta. Pediatr Res 13: 236-240

13. Di Marco PN, Ghisalberti AV, Martin CE, Oliver IT (1978) Perinatal changes in liver corticosterone, serum insulin and plasma glucagon and corticosterone in the rat. Eur J Biochem 87: 243-247

14. Blazquez E, Sugase T, Blazquez M, Foà PP (1974) Neonatal changes in the concentration of rat liver cyclic AMP and of serum glucose, free fatty acids, insulin, pancreatic and total glucagon in man and in the rat. J Lab Clin Med 83: 957-967

15. Girard J, Bal D, Assan R (1972) Glucagon secretion during the early postnatal period in the rat. Horm Metab Res 4: $168-170$

16. Girard JR, Kervran A, Assan R (1975) Functional maturation of the A cell in the rat. In: Camerini Davalos RA, Cole HS (ed) Early diabetes in early life. Academic Press, New York, p 51-71

17. Hetenyi G, Kovacevic N, Hall SEH, Vranic M (1976) Plasma glucagon in pups, decreased by fasting, unaffected by somatostatin or hypoglycemia. Am J Physiol 231: 1377-1382

18. Bloom SR, Edwards AV, Hardy RN (1977) Adrenal and pancreatic endocrine responses to hypoxia and hypercapnia in the calf. J Physiol (Lond) 269: 131-154

19. Smith CH, Adcock EW, Teasdale F, Meschia G, Battaglia FC (1973) Placental aminoacid uptake: tissue preparation, kinetics and preincubation effect. Am J Physiol 224: 558-564

20. Simmons MA, Jones D, Battaglia FC, Meschia G (1978) Insulin effect on fetal glucose utilization. Pediatr Res 12: 90-92

Received: June 16, 1980, and in revised form: November 11, 1980

\author{
Dr. F. Sodoyez-Goffaux \\ Department of Paediatrics \\ Hôpital de Bavière \\ University of Liège \\ Bd. de la Constitution 66 \\ $B-4020$ Liège \\ Belgium
}

